\title{
Prevalence of abnormal cervical cytology and HPV DNA positivity among HIV positive women
}

\author{
Sunita Malik $^{1}$, Supriti Kumari ${ }^{1}$, Harsha S. Gaikwad ${ }^{1}$, Archana Mishra ${ }^{1 *}$, Mausumi Bhardwaj ${ }^{2}$
}

${ }^{1}$ Department of Obstetrics and Gynecology, Vardhman Mahavir Medical College and Safdarjung Hospital, New Delhi, India

${ }^{2}$ Division of Molecular Genetics and Biochemistry, Institute of Cytology and Preventive Oncology (ICMR), Noida, Uttar Pradesh, India

Received: 18 June 2019

Accepted: 31 July 2019

\section{*Correspondence:}

Dr. Archana Mishra,

E-mail: drarchanamishra@rediffmail.com

Copyright: ( ) the author(s), publisher and licensee Medip Academy. This is an open-access article distributed under the terms of the Creative Commons Attribution Non-Commercial License, which permits unrestricted non-commercial use, distribution, and reproduction in any medium, provided the original work is properly cited.

\section{ABSTRACT}

Background: The relationship among HIV, HPV, and development of CIN is complex and incompletely understood. Present study is undertaken to find out the prevalence and relationship of abnormal cervical cytology and HPV infection in HIV positive women.

Methods: This was a cross-sectional, case control study conducted on 95 HIV seropositive and 95 seronegative women. Specimen was collected from the cervix for HPV DNA testing, subtyping and cytology.

Results: HPV DNA positivity was higher in seropositive group (18.6\% vs. $7.4 \%)$. Premalignant conditions were found only in seropositive group. At CD4 count <249 HPV DNA positivity was 53\%, at 250-499 the percentage of HPV DNA positivity was $31 \%$ and at $>500$ HPV DNA positivity was $19 \%$.

Conclusions: Prevalence of abnormal cytology and HPV DNA positivity is higher amongst HIV positive women and there is an association between HPV DNA positivity with lower CD4 counts.

Keywords: Abnormal cytology, Cervix, HIV, HPV infection

\section{INTRODUCTION}

There are 110 types of HPV infections known and out of which only half infect the genital tract. According to IARC WHO classification only 13 types are carcinogenic and rest 7 are possibly carcinogenic. Out of carcinogenic ones are HPV -16, 18, 31, 33, 35, 39, 45, 51, 52, 56, 58, 59 and $68 .{ }^{1} \mathrm{HIV}$ infection causes impaired cell mediated immunity which in turn is responsible for persistent HPV infection and increase risk for abnormal PAP Test. ${ }^{2,3}$

HIV seropositive women if affected by high risk HPV types it progresses rapidly to precancerous lesion and then cervical cancer as compared to seronegative women. The relationship among human immunodeficiency virus, Human pappiloma virus, and development of Cervical
Intraepithelial Neoplasia are undoubtedly complex and incompletely understood. Present study is an attempt to find out the prevalence and relationship of abnormal cervical cytology and HPV infection in HIV positive women. This study was conducted to determine the gynaecologic characteristics related with HIV infection, and also to find out prevalence of abnormal cytology either due to Human Papillomavirus, and highlighting the importance of cervical cancer screening program in HIV positive women.

\section{METHODS}

This was a cross-sectional, case control study which was conducted in the Department of Obstetrics and Gynaecology and Antiretroviral Treatment (ART) clinic 
of a tertiary care centre of North India after ethical clearance from the Institute. Study was conducted on total 190 women. In the study group (Group A) 95 HIV positive women were included from Art clinic and equal numbers of HIV negative women were recruited as controls (Group B). Controls were recruited from women of almost same age and parity coming to gynecology OPD for any gynecological problem or advice.

\section{Inclusion criteria}

- All consenting HIV positive women during the study period of one year.

\section{Exclusion criteria}

- Presence subjects not willing to participate in the study

- Previously diagnosed abnormal cervical cytology.

All subjects were counselled and an informed consent was taken. HIV status of control group was confirmed by blood test (ELISA). All HIV positive women of study group were also assessed for CD4 cells counts. They were evaluated thoroughly by history and examination. Specimen was collected from the cervix using cytobrush for HPV DNA testing, sub-typing and cytology. Results of cytology were classified by using the Bethesda classification system. After collection specimen was placed in a transport medium (Phosphate buffer Saline Medium) and frozen at $-20 \mathrm{C}$ until testing. HPV DNA was detected with the polymerase chain reaction (PCR) based method using HPV L1 consensus primer (MY11 and MY09) and control primer set PC04/GH2O. Positive sample was defined as those containing an ethidiumbromide-stained band of the correct mol. wt. (450bps) after amplification and $1.5 \%$ agrose gel electrophoresis. Furthermore, adequacy of negative sample for PCR analysis, i.e absence of inhibitors, was assessed by the amplification of a fragment of $\beta$-globin gene. For HPV DNA-positive sample, and typing was done by PCR using type specific primers for HPV16, HPV18, HPV6 and HPV11.

\section{Statistical analysis}

Data analysis was done using the relevant statistical tool. The statistical significance was determined by using Chi square test with 5 percent level of significance $(\mathrm{P}<0.5)$, and Power of the study was $90 \%$. Women were compared using student $\mathrm{t}$ test for continuous variable and Chi Square for categorical variables factor like age, CD4 count, HIV -1 RNA, education employment, parity, complaints, number of sexual partners and age of first intercourse.

\section{RESULTS}

While comparing the Demographic characteristics of cases and controls, no significant difference was found in terms of age, parity, socioeconomic status, educational status etc. Most of the subjects of both groups belonged to age group 25-34 years. Mean age of the cases was 31.9 years. Most of the women in both groups were multiparous. Comparing the contraceptive use condom was the most used contraceptive in HIV positive women $(16 \%)$ and intrauterine contraceptive device was the most used contraceptive in HIV negative women (7.4\%). Presenting clinical symptoms of women of HIV seropositive group and HIV seronegative women is described in Table 1.

Most of the patients were asymptomatic in both the groups. In both the groups discharge per vaginum is the most common presenting complaint followed by dysuria. Pain in abdomen was more commonly encountered in seronegative group. Infertility and postcoital bleeding was present only in HIV seronegative group.

Table 1: Distribution of clinical symptoms in Group A and Group B.

\begin{tabular}{|lllll|}
\hline \multirow{2}{*}{$\begin{array}{l}\text { Clinical } \\
\text { symptoms }\end{array}$} & \multicolumn{2}{l}{$\begin{array}{l}\text { HIV Positive } \\
\text { (Group A) }\end{array}$} & \multicolumn{2}{l|}{$\begin{array}{l}\text { HIV Negative } \\
\text { (Group B })\end{array}$} \\
\hline Discharge & 17.0 & $\mathbf{\%}$ & No. & \% \\
\hline Dysuria & 6.0 & 6.3 & 3.0 & 3.2 \\
\hline Infertility & 0.0 & 0.0 & 3.0 & 3.2 \\
\hline $\begin{array}{l}\text { Itchiness of } \\
\text { vulva }\end{array}$ & 4.0 & 4.2 & 0.0 & 0.0 \\
\hline Menorrhagia & 0.0 & 0.0 & 9.0 & 8.4 \\
\hline $\begin{array}{l}\text { Pain in lower } \\
\text { abdomen }\end{array}$ & 7.0 & 7.4 & 16.0 & 16.8 \\
\hline $\begin{array}{l}\text { Post coital } \\
\text { bleeding }\end{array}$ & 0.0 & 0.0 & 1.0 & 1.1 \\
\hline Prolapse & 1.0 & 1.1 & 1.0 & 1.1 \\
\hline
\end{tabular}

$\mathrm{P}=0.006$

Table 2: Distribution of HPV among Group A and Group B.

\begin{tabular}{|lllll|}
\hline HIPV & $\begin{array}{l}\text { HIV positive } \\
\text { (Group A) }\end{array}$ & \multicolumn{2}{l|}{$\begin{array}{l}\text { HIV Negative } \\
\text { (Group B) }\end{array}$} \\
\hline No. (95) & \% & No. (95) & \% \\
\hline Negative & 78 & 82.3 & 88 & 92.6 \\
\hline Positive & 17 & 18.6 & 7 & 7.4 \\
\hline $\begin{array}{l}\text { HPV 16 type } \\
\text { Hype 16+18 }\end{array}$ & 16 & 17.6 & 7 & 7.4 \\
\hline
\end{tabular}

$\mathrm{P}=0.043$.

Table 2 shows the distribution of Human Pappiloma Virus infection in study group and control group. HIV seropositive group has significantly higher number of HPV Positivity (18.6\% vs. 7.4\%). HIV 16 is most common genotype observed. Even one patient has both HPV 16 and 18 positive. 
Table 3: Distribution of abnormal cytology among Group A and Group B.

\begin{tabular}{|c|c|c|c|c|}
\hline \multirow[t]{2}{*}{ Cytology } & \multicolumn{2}{|c|}{$\begin{array}{l}\text { HIV positive } \\
\text { (group A) }\end{array}$} & \multicolumn{2}{|c|}{$\begin{array}{l}\text { HIV Negative } \\
\text { (group B) }\end{array}$} \\
\hline & No. (79) & $\%$ & No. (51) & $\%$ \\
\hline Inflammation & 62 & 78 & 46 & 90 \\
\hline HPV infection & 8 & 10 & 5 & 10 \\
\hline AGC & 2 & 3 & 0 & 0 \\
\hline ASCUS & 1 & 1 & 0 & 0 \\
\hline LSIL & 4 & 5 & 0 & 0 \\
\hline HSIL & 1 & 1 & 0 & 0 \\
\hline $\begin{array}{l}\text { Cell suspicious of } \\
\text { malignancy }\end{array}$ & 1 & 1 & 0 & 0 \\
\hline
\end{tabular}

Association of abnormal cytology in both the groups is described in Table 3. Out of 190 subjects 130 had abnormal cytology. $83 \%$ of HIV positive woman had abnormal cytology while only $48.45 \%$ of HIV seronegative women had abnormal cytology. Out of 130 abnormal smears majority of them had inflammatory smear. $65 \%$ of $\mathrm{HIV}$ positive and $48.4 \%$ of HIV seronegative women had inflammatory smears.HPV infection on cytology smear found in eight HIV positive women and five seronegative women. Out of these eight HIV positive women, one had infection associated with Gardenella organism too which was seen on PAP smear. Premalignant condition like AGC, ASCUS, LSIL, HSIL and cell suspicious of malignancy were found in only in HIV positive group $(3 \%, 1 \%, 5 \%, 1 \%, 1 \%$ respectively).

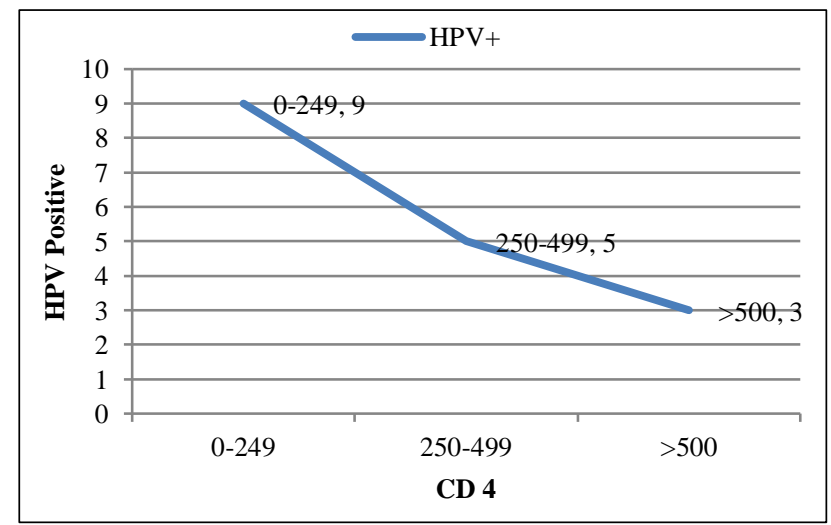

$\mathrm{P}=0.028$; Pearson correlation (-0.982).

\section{Figure 1: Correlation of HPV positivity with CD4 count.}

Out of 95 HIV positive women $27.37 \%$ had CD4 count below 249, 44.21\% women had CD4 count between 250499 and $28.42 \%$ women had CD4 count $>500$. A very important observation of our study was this correlation of HPV positivity with CD4 count as described in Figure 1. At CD4 count <249 HPV DNA positivity were $53 \%$. Along with higher number of CD4 counts in HIV positive women the percentage of HPV DNA positivity decreased. In CD4 counts between 250-499 the percentage of HPV DNA positivity were $31 \%$ and at CD4 count $>500 \mathrm{HPV}$ DNA positivity was $19 \%$.
There was no significant association found between ART treatment and HPV DNA positivity. Out of $17 \mathrm{HPV}$ positive, 2 had not started ART treatment and 15 were on ART treatment. HPV positivity was more (88\%) in women in taking ART VS $12 \%$ in women not taking the same. Out of 95 HIV positive twenty seven women were not on any ART treatment. Women who were taking ART for 6-12 months duration were $15.8 \%$, for 12.1-24 months duration were $15.8 \%$ and for more than 24 months were $28.4 \%$.

\section{DISCUSSION}

Acquisition of both Human pappiloma Virus and Human immunodeficiency virus is related to common behavioral risk factors such as multiple sex partners which make the assessment of casual relationship difficult to assess. Persistent HPV infection may lead to CIN 1 which usually resolve on its own in majority of cases. Only in minority of cases these lesions progress to CIN 2, CIN 3, adenocarcinoma in situ and cervical cancer. If HPV infection occurs in HIV positive women there is much more rapid progression to higher grade and invasive lesions. In fact chances of detection of HPV infection increases rapidly within early years of seroconversion which is suggestive of mucosal immune dysfunction or HIV related change in the molecular pathway leading to cervical cancer. ${ }^{3}$ Immunosuppression makes the infected women more prone for persistent infection and progressive dysfunction in immune system along with failure to curb the neoplastic changes. In present study HPV infection was significantly higher in study group than control group (18.6\% vs. $7.4 \%)$. This observation can be explained by the fact that immune suppression due to HIV infection causes impaired clearance of HPV thereby causing positivity for the same more in the study group. ${ }^{4,5}$ Another study has reported co- infection with HPV infection was seen in $69 \%$ in cases as compared with $44 \%$ in HIV seronegative women. ${ }^{6}$ High-risk HPV type like HPV 18 were exclusively seen in HIV positive women and HPV 16 was significantly higher in study group (17\% vs. 7.4\%). Researchers have reported chances of Abnormal PAP smear to be 4.3 fold higher in HIV positive women. In present study abnormal cytology in HIV seropositive women was found to be $83.2 \%$ which was significantly higher than HIV negative women where it was $48.45 \%(\mathrm{p}=0.015)$. Cytological features like AGC, ASCUS, LSIL and HSIL were exclusively seen in the study group. Cell suspicious of malignancy was found in $1 \%$ of the study group while none of the control group. A recent study from Eastern parts of India reported prevalence of abnormal cervical cytology as follows. (74.33\%) negative for intraepithelial lesions (NILM) cytology in $74.33 \%$, atypical squamous cells of undetermined significance (ASCUS) in 1.60\%, low-grade squamous intraepithelial lesions (LSIL) in $17.11 \%$, highgrade squamous intraepithelial lesions (HSIL) in $5.35 \%$ and carcinoma cervix in $1.60 \%$ cases. ${ }^{7}$ In present study we also found the prevalence of HPV DNA significantly higher in HIV positive women than in controls $(18.6 \%$ 
vs. 7.4\%). Although the difference is much higher in other studies in comparison to present study can be explained due to variation in sample size. Although there are some studies which after years of observation have reported that most abnormal Papanicolaou tests in HIV seropositive women are atypical or low grade lesions not the high grade lesions leading to the high grade lesions leading to precancerous state. ${ }^{8}$ HPV 16,18 and other high HPV Types are the risk factors of cervical cancer and for cervical intraepithelial neoplasia and its precursors. ${ }^{8} \mathrm{~A}$ significant correlation was found between CD4 count and HPV DNA reports with $\mathrm{p}$ value 0.121 and Pearson correlation coefficient - 0.982. 53\% of HPV DNA positive women had CD4 count $<250 / \mathrm{mm}^{3}, 31 \%$ had CD4 count $250-499 / \mathrm{mm}^{3}$. Many other studies have shown the similar observation. ${ }^{9,10}$ In present study no significant association was found between duration of ART and HPV positivity. it was observed that the HPV DNA positivity was more i.e. $88 \%$ in women taking HAART versus $12 \%$ in women not taking the same. This could be because the women recruited for HAART were the ones with low CD4 count in which the lower immunity caused higher prevalence of HPV infection. Due to lack of follow up in our study a definite conclusion regarding the HPV DNA positivity over a time period and regression of SIL in women taking HAART could not be made. Various studies have shown a contrary picture where the prevalence of HPV was lower in women taking HAART. Observation is supported by a recent systemic review from Sub Saharan Countries. ${ }^{5}$ Another aspect of this observation is that initiation of ART increases longevity. Moreover frequent contact with health facility increases chances of screening and diagnosis of cervical lesions. ${ }^{11}$ Opinion from another author is that if HAART is started at high CD4 Count and in compliant patients who adhered to regimen for long duration, it decreases the incidence of invasive cervical cancer. $^{12}$

\section{CONCLUSION}

It is inferred that the prevalence of abnormal cytology and HPV DNA positivity is higher amongst HIV positive women. Also, there is an association between HPV DNA positivity and CD4 counts which showed higher prevalence of HPV infection in subjects with low CD4 counts.

\section{Funding: No funding sources}

Conflict of interest: None declared

Ethical approval: The study was approved by the Institutional Ethics Committee

\section{REFERENCES}

1. Guillarmod MJ, Pasquier J, Greub G, Bongiovanni M, Achtari C, Sahli R, Impact of
HPV vaccination with Gardasil® in Switzerland. BMC Infect Dis. 2017; 17:790.

2. Verma M, Erwin S, Abedi V, Hontecillas R, Hoops $\mathrm{S}$, Leber A. Modeling the mechanisms by which HIV-associated immune suppression influences HPV persistence at the oral mucosa. PLoS One. 2017;12(1):e0168133.

3. Looker KJ, Rönn MM, Brock PM, Brisson M, Drolet M, Mayaud P, et al. Evidence of synergistic relationships between HIV and Human Papillomavirus (HPV): systematic reviews and meta-analyses of longitudinal studies of HPV acquisition and clearance by HIV status, and of HIV acquisition by HPV status. J Int AIDS Soc. 2018;21(6):e25110.

4. Denny LA, Franceschi S, de Sanjosé S, Heard I, Moscicki AB, Palefsky J. Human papillomavirus, human immunodeficiency virus and immunosuppression. Vaccine. 2012;30 Suppl 5:F168-74.

5. Menon S, Rossi R, Zdraveska N, Kariisa M, Acharya SD, Vanden Broeck D, et al. Associations between highly active antiretroviral therapy and the presence of HPV, premalignant and malignant cervical lesions in sub- Saharan Africa, a systematic review: current evidence and directions for future research. BMJ Open. 2017;7(8):e015123.

6. Camargo M, Leon SC, Munoz M, Sanchez R, Herrera DP. Human papillomavirus detection in women with and without human immunodeficiency virus infection in Colombia. BMC Cancer. 2014; 14:451.

7. Chakravarty J, Chourasia A, Thakur M, Singh AK, Sunder S, Agrawal NR. Prevalence of human papillomavirus infection and cervical abnormalities in HIV-positive women in eastern India. Indian $\mathbf{J}$ Med Res. 2016;143(1):79-86.

8. Massad LS, Xie X, D'Souza G. Incidence of cervical precancers among HIV-seropositive women. Am J Obstet Gynecol. 2015;212:606.e1-8.

9. Hanisch RA, Sow PS, Toure M, Dem A, Dembele $\mathrm{B}$, Toure $\mathrm{P}$, et al. For the University of WashingtonDakar HIV and Cervical Cancer Study Group Influence of HIV-1 and/or HIV-2 infection and CD4 count on cervical HPV DNA detection in women from Senegal, West Africa. J Clin Virol. 2013;58(4):696-702.

10. Madan A, Patil S, Nakates L. A Study of Pap Smear in HIV-Positive Females. The J Obstet Gynecol India. 2016;66(6):453-9.

11. Kelly H, Weiss AH, Benavente Y, Sanjose SD, Mayaud P. ART and HPV Review Group, Association of antiretroviral therapy with high-risk human papillomavirus, cervical intraepithelial neoplasia, and invasive cervical cancer in women living with HIV: a systematic review and metaanalysis Lancet HIV. 2018;5(1):e45-e58.

12. Clifford GM, Franceschi S, Keiser O. Immunodeficiency and the risk of cervical intraepithelial neoplasia $2 / 3$ and cervical cancer: A 
nested case-control study in the Swiss HIV cohort study. Int J Cancer. 2016;138:1732-40.
Cite this article as: Malik S, Kumari S, Gaikwad HS, Mishra A, Bhardwaj M. Prevalence of abnormal cervical cytology and HPV DNA positivity among HIV positive women. Int J Reprod Contracept Obstet Gynecol 2019;8:3649-53. 